\title{
THE INVISIBILITY OF THE BLACK POPULATION IN MODERN SLAVERY: EVIDENCE BASED ON CONDITIONS OF SOCIAL VULNERABILITY
}

\author{
A invisibilização do negro no trabalho escravo contemporâneo: \\ evidências a partir das condições de vulnerabilidade social
}

\author{
Rodrigo Martins Baptista* \\ Mariana Lima Bandeira** \\ Maria Tereza Saraiva de Souza***
}

\begin{abstract}
The aim of this article is to identify the associations between the social conditions of vulnerability and the racial profile of modern slavery. It presents findings from qualitative research developed between 2011 and 2016 on the institutional and organizational mechanisms responsible for the maintenance of modern slavery in Brazil, based on the theoretical framework of Crane (2013), Bales (2004) and Datta and Bales (2013; 2014). From a methodological point of view, this study makes use of socioeconomic, geographic, sociocultural and social vulnerability indicators produced mainly by the reports published by members of the National Pact for the Eradication of Slave Labor Institute (Instituto Pacto Nacional pela Erradicação do Trabalho Escravo - InPACTO) and the public sector. The article's contribution centers on the incorporation of the variable race and color, indicating its relation to modern slavery, in addition to showing how contemporary slave labor coexists with the economically representative productive chains in Brazil, some of which are members of InPACTO.
\end{abstract}

Keywords: Contemporary slavery. Vulnerability. Race. Skin color.

\section{RESUMO}

Este artigo objetiva identificar as associações entre as condições sociais de vulnerabilidade e o perfil racial da escravidão contemporânea. Ele é fruto de um recorte de uma pesquisa qualitativa desenvolvida entre 2011 e 2016 sobre os mecanismos institucionais e organizacionais responsáveis pelo sustento da escravidão contemporânea no Brasil, fundamentado na estrutura teórica de Crane (2013), Bales (2004) e Datta e Bales (2013; 2014). Do ponto de vista metodológico, este estudo faz uso dos indicadores socioeconômicos, geográficos, socioculturais e de vulnerabilidade social produzidos principalmente pelos relatórios publicados pelos membros do Instituto Pacto Nacional pela Erradicação do Trabalho Escravo - InPACTO e do poder público. A contribuição do artigo diz respeito à incorporação da variável preditora raça e cor, indicando sua relação com a escravidão moderna, além de o trabalho escravo contemporâneo coexistir com as cadeias produtivas economicamente representativas no Brasil, sendo algumas delas, inclusive, membros do InPacto.

Palavras-chave: Escravidão contemporânea. Vulnerabilidade. Raça. Cor.

\footnotetext{
* Professor do Centro Universitário Senac e da Universidade Anhembi Morumbi, Postdoctoral fellow da University of Kassel, Kassel, Germany, e Doutor em Administração pelo Centro Universitário Fundação Educacional Inaciana Padre Sabóia de Medeiros (FEI). E-mail: rodrigo2w2@gmail.com. ORCID: 0000-0003-0157-1510

** Professora Titular da Universidad Andina Simón Bolívar (Equador) e Professora Convidada da Universidad Estatal de Milagro (Equador) e do Programa de Pós-graduação em Administração do Centro Universitário Fundação Educacional Inaciana Padre Sabóia de Medeiros (FEI). E-mail: limabandeira.mariana@gmail.com. ORCID: 0000-0003-2277-9847

*** Professora Adjunta do Programa de Pós-Graduação do Centro Universitário Fundação Educacional Inaciana Padre Sabóia de Medeiros (FEI). Doutora em Administração de Empresas pela Escola de Administração de Empresas de São Paulo da Fundação Getúlio Vargas (EAESP/FGV). E-mail: mtereza@fei.edu.br. E-mail: mtereza@ fei.edu.br. ORCID: 0000-0003-4514-2021
} 


\section{INTRODUCTION}

$\mathrm{C}$ ontemporary slavery exists and affects approximately 160,600 workers per year in Brazil and 48.5 million in the world, manifested in the form of degrading and unsustainable labor relations that include factors such as the absence of freedom, exhausting working hours, and physical, moral and psychological violence that deny the basic rights of the workers involved (REPÓRTER BRASIL, 2011; CAZETTA, 2007; CRANE, 2013; WALK FREE FOUNDATION, 2014; DATTA; BALES, 2014).

Modern slavery ${ }^{1}$ is a global phenomenon present in various countries. The phenomenon may be related to economic or sexual exploitation and may be an outcome of low schooling and the population explosion at global level, correlated with reduced labor costs. Slavery intentionally transforms human beings into disposable parts, called thus due to the fact that many workers are easily replaced (BALES, 2002; 20112; DATTA; BALES, 2014, CRANE, 2013; OIT, 2004). As a rule, the phenomenon of modern slave labor tends to be considered a peripheral problem for many of those involved, even though governments and non-governmental organizations (NGOs) are working to combat this issue (BALES, 2004). Another dilemma of contemporary slave labor is related to the low amount of recognizable debate in the social sciences, as shown by the incipient publication of works on the theme and the fact that it remains virtually absent in the field of organizational studies (BALES, 2004; 2011; COOKE, 2003; CRANE, 2013; BALES; TRODD; WILLIAMSON, 2009).

For Crane (2013) and Bales (2004; 2001), conditions of socioeconomic, sociocultural and geographic vulnerability and the ineffectiveness of the State form a structural inertia, since they are used by informal and criminal work networks to sustain slavery practices in the present day, through the so-called 'hidden mechanisms'. Bourdieu (1989, p. 8) provides the means to understand the 'invisibility' of these 'hidden mechanisms,' when he attributes their effectiveness to the complicity of those who do not want to know that they are subject to them or even that they operate them. Bourdieu (1989) refers to symbolic power, indicating that it is a form of establishing a logical order that in some form regulates a social reality. In the context of this article, the field as defined by Bourdieu (1989) is understood as the social space shared by the different actors involved in contemporary slavery, which possesses its own structure (habitus) and is relatively autonomous vis-à-vis other social spaces with specific objectives that guarantee a particular logic of operation and structuration. Bourdieu (1989, p. 9-10) proceeds to argue that structured and structuring mechanisms of the symbolic system act as "means of communication and knowledge production", but also perform political functions, as it helps to ensure that one class dominates another (symbolic violence). For now, it is crucial to emphasize that it is not a question of analyzing the relations of force within the field of power of contemporary slavery, but of establishing a relationship between the variables of the phenomenon and the racial profile, based on the identification of the elements that structure the field.

1. The terms modern and contemporary will be used as synonyms in this work, since the literature does not establish differences in the use of these adjectives when referring to the new configuration of slavery.

2. In this article, all reference to this work are verbal information obtained at the 4th International Seminar of the National Pact for the Eradication of Slave Labor held in Brasilia. 
This article presents findings from a study developed between 2011 and 2016 on the institutional and organizational mechanisms responsible for sustaining contemporary slavery in Brazil. The aim is to identify the associations between social conditions of vulnerability and the racial profile of contemporary slavery. Until very recently, the official data in Brazil did not include the racial issue as one of the elements contributing to contemporary slavery.

From the methodological viewpoint, this study makes use of socioeconomic, geographic, sociocultural and social vulnerability indicators produced mainly in the reports published by members of InPACTO (The National Pact for the Eradication of Slave Labor Institute/Instituto Pacto Nacional pela Erradicação do Trabalho Escravo) ${ }^{3}$ and public authorities. It also presents results from the observation of the events promoted by InPACTO and semi-structured interviews conducted from 2011 to 2016. The object of study was InPACTO itself, which establishes commercial rules among the associated signatories that voluntarily assume responsibility for fulfilling the agreements and contractual clauses with their suppliers throughout the production chain.

The text is structured in six sections, including the present introduction. The second section is dedicated to an overview of contemporary slavery, describing its main characteristics and conceptual background. This description includes the main studies to have explored the issue, as well as a set of data and assumptions designed to show the configuration of contemporary slavery in Brazil. The third section describes the methodological approach used in the research, indicating the data sources and the procedures used for their analysis. The fourth section presents and discusses the research findings, demonstrating the relationship between the predictor variables of contemporary slavery and the main sociodemographic data. The fifth section details propositions that organize the data in accordance with the constructed theoretical arguments. The last section outlines some final reflections on the theme under discussion, pointing to challenges and proposals for future research.

\section{CONTEMPORARY SLAVERY: CONCEPTS AND CONFIGURATION}

From the 1990s, Bales (2004) initiated his study of the configuration of the "new slavery' in five countries, using the multiple case study as a methodology: Brazil, Mauritania, India, Thailand and Pakistan. Kevin Bales is considered one of the leading authors on the theme worldwide (OIT, 2009). His research has been grounded in Conventions 29 and 105 of the International Labor Organization, seeking to discuss the introduction of legal regulations in the diverse countries attempting to deal with the problem. Several victims, slave recruiters, business owners, NGOs, governments and local communities were interviewed. The researchers concealed the objective of the research from some interviewees, since the issue of slave labor could not be openly debated by the companies, small businesses or recruiters.

The patterns discovered in Brazil, Mauritania, India, Thailand and Pakistan led to the identification of three key factors in the new slavery: the intense population growth; the

3. InPACTO was cited as a benchmark of best practices by the International Labor Organization (OIT, 2009; InPACTO, 2015). 
globalization and modernization of world agriculture; and the ease with which social rules are violated.

The first factor, the dramatic growth in the global population, becomes clear when we observe that over the last 50 years a demographic explosion has taken place with the world population rising from 2 billion to 7 billion people. This fact has driven down the value of labor on the world market, oriented towards the generation of value and optimization of costs in production chains, principally in activities related to raw material extraction (BALLOU, 2007; BALES; ROBBINS, 2001; GOLD; TRAUTRIMS; TRODD, 2015; SAKAMOTO, 2008). The second key factor - the globalization and modernization of world agriculture - forced small farmers without capital resources to search for other means of survival (MARTINS, 2008; LUXEMBURGO, 1984). Peasants and small producers adapted their tasks and routines to meet the demands of big rural producers and, in situations where they lacked the conditions to sustain themselves, also showed a strong trend towards migration to cities (MARTINS, 2008; LUXEMBURGO, 1984; BALES, 2004). ${ }^{4}$ Finally, the third key factor is based on the violation of social rules and traditional relations of legal work as an outcome of greed, corruption and violence, especially in developing countries (BALES, 2004).

Later, Datta and Bales (2013) estimated the incidence of slave labor through the results of a survey and secondary data from the pioneering research of Pennington et al. (2009). The information used included data on national population sizes, average family size, estimated number of families in the country, and the number of families cited in reports on trafficked and enslaved human beings. Human trafficking was used since it comprises the first stage before a condition of modern slavery (CRANE, 2013). Datta and Bales (2013) argue that, based on the estimated number of trafficking victims/enslaved individuals per country, it is possible to calculate the proportion of enslaved victims. According to the Walk Free Foundation (2014), the number of workers in conditions analogous to slavery in Brazil was 209,622 in 2015, with an interval below 200,000 and above 220,000. Worldwide, modern slavery directly affects 45.8 million people employed for both sexual and economic purposes.

The conditions of population growth, globalization and modernization of agriculture, associated with the opportunity to exploit workers, resulted in what was termed as 'hidden mechanism' (BALES, 2004; CRANE, 2013; AGUINIS; GLAVAS 2012). ${ }^{5}$ Hidden mechanisms are the outcome of institutional and organizational articulations that maintain and sustain slavery (BALES, 2004; CRANE, 2013). Pursuing the same line of argument, Linstead, Maréchal and Griffin (2014) use the term 'dysfunctional conformity' to describe a practice commonly found in management, the logic of which is to constantly search for the cheapest available labor, reducing resources to a minimum in order to diminish unit production costs.

4. The same pattern was seen in Brazil: in 1960 the urban population was 41 million, rising to more than 170 million in 2015. This population increase ended up generating opportunities for exploiting workers lacking the most basic resources and became a fertile field for slavery practices in both rural and urban environments.

5. The term 'hidden mechanism' was discussed by Aguinis and Glavas (2012, p. 953) in the theoretical review of Corporate Social Responsibility. The term can be associated with what Crane (2013) calls the institutional deflection of organizations. 
As recently as 2013, Andrew Crane presented the theoretical model of contemporary slavery as a management practice. The theoretical structure of this model was elaborated with the following elements: human trafficking, economics of crime, informal business ventures and organized crime (BECKER, 1968; DICK, 1995; UNITED NATIONS, 2001; WEBB et al., 2009; SALT; STEIN, 2002; BALES, 2004). Crane (2013) divides the model into three parts: the conditions for slavery to occur, the capacities of organizations to exploit these conditions, and, finally, the support and adaptation of criminal networks that maintain and protect themselves from punishment for criminal practices in the face of multiple external pressures. The author examines the conditions for slavery in an industrial, socioeconomic, geographical, cultural and regulatory context.

Crane (2013) discusses the capacity of business ventures to exploit the conditions and, at the same time, annul the critical views of the victims of modern slavery. The latter generally fail to recognize that they are subject to slavery practices. Finally, the author speaks of the reproduction of these practices and the adaptation of the responses of criminal networks to institutional pressures. This dynamic is very similar to what Bourdieu (1990) identifies as the set of forces within the field that keep the 'game' functioning among the actors - in this context, the symbolic power exerted by mechanisms that conceal domination and make it acceptable and even desirable for victims of modern slavery.

Crane (2013) shows that multinational companies and small businesses exploit institutional niches at the same time as they develop the capacities to isolate, sustain and shape slavery routines and tasks to gain competitive advantages. As a result, they occupy a double position in the field: legitimate and illegitimate simultaneously, since they need careful positioning to take advantage of institutional spaces that can also be strategically exploited to support unlawful practices (LINDSAY, 2010; CRANE, 2013). Crane (2013) argues that certain institutional and organizational characteristics and contexts can contribute to the successful management of these informal or illegal organizations. Sometimes the institutional environment fails to attain the ideal form for complying with the rules and norms of conduct. In such cases where there is insufficient adaptation to norms, an institutional deformity arises since the norm is ineffectively institutionalized and thus unable to fulfil its function (DIMAGGIO; POWELL, 1983; SCOTT, 1995).

Based on the bibliographic survey conducted in this research, we argue that the basic premise of modern slavery is related not just to the social psychological condition, but above all to relations of economic-political power (BALES; ROBBINS, 2001; BALES, 2004; DATTA; BALES, 2014; GOLD; TRAUTRAMS; TRODD, 2015; CRANE, 2013). This perhaps comprises one of the repertoires of meaning re-elaborated in response to the contemporary capitalist context involving a globalized and competitive scenario in diverse production chains (GOLD; TRAUTRAMS; TRODD, 2015). Along these lines, the set of variables that constitute the economic-political panorama of modern slavery, what we call predictor variables, were used in the analysis of the data, as Table 1 shows. 
Table 1 - Propositions and Predictor Variables of Modern Slavery

\begin{tabular}{|c|c|c|c|}
\hline Authors (Year) & $\begin{array}{l}\text { Category of } \\
\text { analysis }\end{array}$ & Proposition & $\begin{array}{l}\text { Predictor variables } \\
\text { of modern slavery }\end{array}$ \\
\hline \multirow[t]{4}{*}{$\begin{array}{c}\text { Bales (2004); } \\
\text { Datta and Bales } \\
\text { (2013; 2014); } \\
\text { Crane (2013); } \\
\text { Bourdieu } \\
(1989 ; 1990)\end{array}$} & $\begin{array}{l}\text { Socioeconomic } \\
\text { context }\end{array}$ & $\begin{array}{l}\text { The exploitation of slave labor, which occurs in } \\
\text { contexts of high unemployment, chronic poverty } \\
\text { and low schooling, stimulates the adoption of } \\
\text { slave labor by business ventures. }\end{array}$ & $\begin{array}{l}\text { Population density, } \\
\text { MHDI and vulne- } \\
\text { rability }\end{array}$ \\
\hline & $\begin{array}{l}\text { Geographic } \\
\text { context }\end{array}$ & $\begin{array}{l}\text { The geographic isolation of the business, combi- } \\
\text { ned with the psychological, political and physical } \\
\text { isolation of workers, stimulates the adoption of } \\
\text { slave labor by business ventures. }\end{array}$ & $\begin{array}{l}\text { Geographic iso- } \\
\text { lation and people } \\
\text { trafficking }\end{array}$ \\
\hline & $\begin{array}{l}\text { Sociodemogra- } \\
\text { phic context }\end{array}$ & $\begin{array}{l}\text { Inequality naturalizes coercive labor relations, } \\
\text { and thus stimulates the adoption of slave labor by } \\
\text { business ventures. }\end{array}$ & Race and color \\
\hline & $\begin{array}{l}\text { Regulatory } \\
\text { context }\end{array}$ & $\begin{array}{l}\text { The absence of an effective regulatory context } \\
\text { capable of imposing sanctions on the exploitation } \\
\text { of labor under slavery-like conditions stimulates } \\
\text { the adoption of slave labor by business ventures. }\end{array}$ & $\begin{array}{l}\text { Inspections and } \\
\text { corruption }\end{array}$ \\
\hline
\end{tabular}

Source: Elaborated by the authors.

The predictor variables are thus called in this article since they help explain the probability of slavery occurrence. We have based the propositions that articulate these variables as predictors on the seminal studies of Pennington et al. (2009), which measured the number of modern slaves in Europe using data on the number of people trafficked, and the research carried out by Datta and Bales $(2013 ; 2014)$. Geographic isolation and the lack of contact with family were important psychological factors in the study, besides the need to obtain employment and income. Other factors include: unemployment, poverty, education and the limited awareness of enslaved victims (CRANE, 2013; FIGUEIRA, 2008). Studies by Bales (2004) in Brazil, Mauritania, India, Thailand and Pakistan indicated the relation between poverty, $\mathrm{HDI}$, vulnerability, corruption and the isolation of enslaved people. Later, Datta and Bales $(2013 ; 2014)$ used research criteria from Pennington et al. (2009) to apply a multiple regression analysis and argue that poverty, social dissatisfaction, corruption, population density and the perception of opportunity, or its absence, can be taken as factors that induce modern slavery. Datta and Bales (2014) presented the significant model for the risk of State instability, freedom of expression, access to financial services, geography and age. The predictor variables indicated a significant result for the transnational variation of slavery throughout Europe (DATTA; BALES, 2014).

\subsection{THE CONCEPT OF SLAVE LABOR IN BRAZIL}

The concept of contemporary slave labor in Brazil advanced in the fight against slavery practices following the changes made to Law 10803/2003 through Article 149 of the Brazilian Penal Code. Article 149 criminalizes the practice of reducing someone "to a condition analogous to a slave", presenting four elements that, combined or in isolation, characterize the crime: a) submission of the worker to forced labor; b) submission to 
exhausting working hours; c) submission to degrading work conditions; d) restrictions on their locomotion (MTE, 2016; 2009; 2012). The term 'analogous' is used in the Law due to the fact that the Brazilian State does not recognize any human being as a 'slave' in the present-day context.

The first paragraph of Article 149 also details that slave labor is characterized by: curbing the use of any means of transport by the worker, maintaining ostensive surveillance in the workplace, or seizing possession of the worker's documents and/or personal objects to retain him or her in the workplace. The penalty for the crime is imprisonment for two to eight years and a fine, as well as the penalty corresponding to the violence used. The penalty may also be increased if the crime was committed against a child or adolescent, or for reasons of racial, color, ethnic, religious or any other type of discrimination.

Conceptual differences exist in the definitions of modern slavery used in Brazil and the rest of the world (OIT, 2005), both in the terms used and in the elements implied by the terms - in other words, their characteristics. The form in which the concept is delimited has a direct impact on the regulatory process and dynamic. The Table 2 below shows the differences in how the topic is treated in the respective legal frameworks:

Table 2 - Comparison of the definitions of contemporary slavery of Brazil and the ILO

\begin{tabular}{|c|c|}
\hline Brazil & ILO \\
\hline \multicolumn{2}{|c|}{ Term } \\
\hline Work analogous to slavery & Forced or compulsory labor \\
\hline \multicolumn{2}{|c|}{ Legislative Framework } \\
\hline Articles 149, 197, 203 and 207 & Convention n. $29-1930$ and n. $105-1957$ \\
\hline \multicolumn{2}{|c|}{ Elements of Slavery } \\
\hline $\begin{array}{l}\text { Lack of freedom, exhausting working hours and } \\
\text { degrading conditions }\end{array}$ & $\begin{array}{c}\text { Coercion, punishment, penalties, threats, } \\
\text { imposition of work }\end{array}$ \\
\hline \multicolumn{2}{|c|}{ Argument delegitimizing the Brazilian concept } \\
\hline Abusive interpretation of the defin & tion of degrading labor conditions \\
\hline
\end{tabular}

Source: OIT, 2009; Melo, 2007. Adapted from OIT (2009; 2014).

Elements such as lack of freedom, exhausting working hours and degrading conditions contribute to the perpetuation of slave labor in Brazil. In February 2017, the National Justice Council (Conselho Nacional de Justiça - CNJ) presented an award to Judge Jaiza Maria Pinto Fraxe of the $3^{\text {rd }}$ Federal Court of Manaus (Amazonas state) for her work in combatting slave labor, as a form of encouraging other judges to endeavor to protect human rights through the social purpose of work (CNJ, 2017).

Even so, a long path remains ahead. Article 149 of the Brazilian Penal Code on slave labor, introduced in 2003 (BRASIL, 2003), presents a text with a certain amount of conceptual elasticity. Parliamentarians, politicians and some business sectors allege that it is impossible to refer to slavery because the legal ownership of another person is prohibited (CAZETTA, 2007; SÃO PAULO, 2015). Based on this argument, auditors and prosecutors 
from the Ministry of Labor and Employment (Ministério de Trabalho e Emprego - MTE) and the Ministry of Labor (Ministério Público do Trabalho - MPT) (MTE, 2011; 2009) argue that the term 'slave labor' refers to "work in conditions analogous to slavery". The expression slave labor allows the interpreter to potentially associate the term 'slavery' with the colonial system of the past.

This elasticity of the concept generates complaints to the Brazilian government and NGOs. Debates surrounding the issue claim that Brazil drifted away from the international concept adopted by ILO. For the latter (OIT, 2004, p. 11), "[...] every form of slave labor is degrading work but the reverse is not always true. What differentiates one concept from the other is freedom". Indeed, ILO Convention 29 establishes the illegality of forced labor, defined as "[...] all work or service which is exacted from any person under the threat of a penalty and for which the person has not offered himself or herself voluntarily" (OIT, 2004, p. 27). However, the border between coercive and non-coercive exploitation is subtle. ILO itself calls attention to the involuntary action of workers faced with the need to find employment. For example, involuntary consciousness can be associated with the lack of employment opportunities combined with a situation of extreme poverty and low levels of education. They have no alternative, therefore, save to accept terrible working conditions.

For Bales, Trodd and Williamson (2009) the ideal would be to have a definition of modern slavery that encompasses all its elements. This could be an ideal solution for the attempts to delegitimize business organizations opposed to the inspection of production chains. In the meantime, these loopholes allow other regulations or laws to be used to redefine slavery practices as less harmful and more acceptable, which to some extent also contribute to rendering the phenomenon invisible.

\section{METHODOLOGICAL TRAJECTORY}

Through a qualitative approach, the research triangulated and analyzed primary and secondary data from 2011 to 2016 . The decision was taken to utilize the testimonies from real cases of workers employed in conditions analogous to slavery in the MTE database. Each real case was transcribed since it depicted the trajectory from recruitment to the practices expressed in Article 149 of the Brazilian Penal Code. In addition to the real cases of the workers, the research compiled secondary data and a bibliography on the theme. The leading of this study also participated in three seminars about modern slavery in Brazil, held in São Paulo and Brasilia, in order to collectdata from conferences and presentations (a total of 26 sources of data)., Also, 12 interviews were held with academics, NGO professionals, civil servants and business representatives. All the interviews, presentations and seminars'conferences were recorded and transcribed using the NVivo software to manage the data. Primary data were collected, such as the observation diary, semi-structured interviews and photo and video records, as well as secondary data such as diverse documents and reports produced by members responsible for coordinating InPACTO.

InPACTO was chosen as a research object due to its internationally recognized work in combatting slave labor and the close liaisons between the signatories (OIT, 2009; InPACTO, 2015). Around 380 companies and institutions are signatories of InPACTO and together these represent more than $22 \%$ of the entire productive business wealth in the 
country (REPÓRTER BRASIL, 2011; OIT 2004). Members of InPACTO range from civil society institutions, NGOs and, principally, companies from sectors such as agriculture, cattle-raising and the textile industry, as well as private banks and a law firm. In the context of InPACTO, discussion focuses on themes concerning institutional measures, some of them informed by the discourse of social responsibility, with the objective of preventing and eradicating slave labor in production chains.

In 2004, the Special Secretariat of Human Rights (Secretaria Especial de Direitos Humanos - SEDH) requested ILO Brazil to fund a study on production chains to identify economic sectors affected by slave labor. Through this study, ILO, the Ethos Institute of Business and Social Responsibility (Instituto Ethos de Empresas e Responsabilidade Social), the NGO Repórter Brasil and the Social Observatory Institute (Instituto Observatório Social - IOS) revealed a network of national and multinational companies that reduced workers to labor conditions analogous to slavery: in other words, 200 national and international companies that sell products and services deriving from enslaved employees (InPACTO, 2015). Provided with this information, ILO supported the Ethos Institute to arrange meetings with the companies identified in the study. The dialogue led to the launch of the National Pact for the Eradication of Slave Labor on May 19 ${ }^{\text {th }}, 2005$ (InPACTO, 2015). The business sector commitment to combat the problem through the adoption of measures involving commercial restrictions on suppliers who employ slave labor was made public through the Pact. In 2014, with the institutional progress of the pact, InPACTO was created - the Pact for the Eradication of Slave Labor Institute. The Institute has the goal of strengthening and broadening the actions realized by the National Pact for the Eradication of Slave Labor, first created in 2005. A governance structure shared by 380 signatories was set up and coordinated by the International Labor Organization (ILO), the Instituto Ethos, the Social Observatory Institute (IOS), and the NGO Repórter Brasil with the collaboration and financial support of the companies Cargill, Carrefour, C\&A, Eletrobrás Eletronorte, Grupo André Maggi and Wal-Mart Brasil. InPACTO's management model unites the interests of companies, civil society organizations, and organizations representing workers to focus on promoting actions of social responsibility (InPACTO, 2015).

The NVivo software assisted in the selection and counting of the sections representing each theoretical category and in the construction of the correlation matrix, used to examine the consistency of the responses between peers with the objective of verifying the saturation of respondents (HOWE; EISENHART, 1990). The data were analyzed using the content analysis technique (BARDIN, 1977). The initial analyses were conducted simultaneously with the data collection to confirm that data saturation had been reached. Over the course of the analytic procedure, multiple sources of evidence were used, as well as input from specialists who provided critical reading of the versions, and triangulation of qualitative techniques supported by software designed to organize and categorize data around the empirical and theoretical categories.

The theoretical categories are the set of predictor variables presented in the theoretical framework of this article: the socioeconomic context, geographic context, sociodemographic context and regulatory context. Considering this background, the survey conducted by the research included the following contextual subcategories: (a) socioeconomic - population density, Municipal Human Development Index (MHDI) and vulnerability; (b) geographic - geographic isolation and human trafficking; (c) sociodemographic - race or 
color; and (d) regulatory - corruption and inspection. However, data on race and color also traverse both the socioeconomic and sociodemographic dimensions.

Over the course of data collection and analysis, the decision was taken to focus on understanding the relationship between the racial, social and cultural patterns and the victims of work analogous to modern slavery in Brazil. Consequently, the data relating to race and color were explored in more depth in the theoretical subcategories. In terms of research procedures, a multicenter approach was adopted given the number of actors involved in confronting the problem and the fact that these actors coordinated certain actions through networks (SECCHI, 2010). On this point, the institutional actors identified in this study connected to this issue are: (i) public authorities; (ii) organized civil society; (iii) the private sector.

\section{ANALYSIS AND DISCUSSION OF RESULTS}

This section presents a systemization of the main sociodemographic data on modern slavery in Brazil, setting out from the premise that this data function as a set of predictor variables for this phenomenon (BALES, 2004, DATTA; BALES, 2013; 2014; CRANE, 2013). Consequently, given the existence of these predictor variables acting concomitantly as a symbolic normative set (habitus), the cycle of modern slavery cannot be modified. The notion of habitus can be understood through the writings of Bourdieu $(1989 ; 1990)$ and his definition of a social field. For the author, social spaces can only be understood through the dual relation involving the interiorization of exteriority and the exteriorization of interiority. The first element - the interiorization of exteriority - relates to the notion of habitus, in which individuals, in the everyday production and reproduction of their practices, embody rules, symbols and concepts of the social reality to which they belong and which constitute them. In this dynamic, the structure of social relations and their conducts are articulated in a process that mixes the subjective and objective dimensions. Secondly, these same practices are the result of the historical evolution of the group and guide social practice - the exteriorization of interiority. Once the schemas of thought, perception and action are embodied, it is possible to ensure compliance with practices and rules, forms of control and patterns based on past experiences. An unconscious and cognitive component exists, but rather than being limited to this dimension, it assumes a multitude of meanings.

Applying these concepts, habitus, in the context of contemporary slavery, is also manifested through the structural inertia exploited by the 'gatos', the workforce recruiters who promise employment and income and fail to deliver either (MTE, 2016; OIT, 2009; InPACTO, 2015). Here it is worth recalling Bourdieu's (1990) definition that fields possess general laws of operation: all fields possess their own rules, with each actor occupying a consolidated position and possessing specific interests in accordance with this position and, in this sense, they organize a game that possesses inherently political traits.

Bales $(2004 ; 2006)$ and Crane (2013) associate modern slavery with economic-political power in the form of hidden mechanisms. Table 1 shows this relational structure of contemporary slavery in Brazil through the analysis of data from the Brazilian states with the highest incidence of freed workers between 1995 and 2015. The data were evaluated vis-à-vis the Municipal Human Development Index (MHDI) and the number/percentage of 
workers from each state who declared their race or color: white, black, brown, indigenous and yellow. The MHDI measures: education - literacy and school enrolment rates; lifespan and life expectancy at birth; and income per capita in relation to GDP. The use of the MHDI aims to provide greater precision and strength to the localized data from each state. The $\mathrm{MHDI}$ is considered high above 0.700 and low between the range of 0.500 and 0.599 .

Table 3 - Operations from GEFM/MTE, MHDI and Data on Race or Color

\begin{tabular}{|c|c|c|c|c|c|c|c|c|c|c|}
\hline \multirow{2}{*}{ States } & \multirow{2}{*}{$\begin{array}{l}\text { HDMI } \\
\text { General }\end{array}$} & \multirow{2}{*}{$\begin{array}{l}\text { HDMI } \\
\text { Income }\end{array}$} & \multirow{2}{*}{$\begin{array}{c}\text { HDMI } \\
\text { Education }\end{array}$} & \multicolumn{5}{|c|}{ Percentage and Number of individuals by race or color } & \multirow{2}{*}{$\begin{array}{c}\text { N. of } \\
\text { operations }\end{array}$} & \multirow{2}{*}{$\begin{array}{c}\text { Freed } \\
\text { workers } \\
1999 \text { to } \\
2015 \\
\end{array}$} \\
\hline & & & & White & Black & Brown & Indigenous & Yellow & & \\
\hline Brazil Av. & 0.727 & 0.739 & 0.637 & $45 \%$ & $9 \%$ & $45 \%$ & $0.0001 \%$ & $0.01 \%$ & 1798 & 50660 \\
\hline MA & 0.639 & 0.612 & 0.562 & 1064371 & 241966 & 3862395 & 2394 & 7187 & 145 & 3227 \\
\hline PA & 0.646 & 0.646 & 0.528 & 1558645 & 616683 & 5915825 & 87548 & 14269 & 399 & 12523 \\
\hline BA & 0.660 & 0.663 & 0.555 & 3004647 & 3043122 & 9059812 & 91482 & 21272 & 82 & 3105 \\
\hline$A C$ & 0.663 & 0.671 & 0.559 & 172219 & 62190 & 537108 & 32938 & 1927 & 24 & 196 \\
\hline PE & 0.673 & 0.673 & 0.574 & 3044387 & 766157 & 5488300 & 39138 & 21512 & 22 & 726 \\
\hline AM & 0.674 & 0.677 & 0.561 & 785697 & 165994 & 2896635 & 96326 & 7808 & 29 & 439 \\
\hline CE & 0.682 & 0.651 & 0.615 & 2530016 & 364692 & 5979370 & 29576 & 19870 & 19 & 535 \\
\hline RO & 0.690 & 0.712 & 0.577 & 557390 & 143189 & 1061556 & 7293 & 3513 & 49 & 896 \\
\hline TO & 0.699 & 0.690 & 0.624 & 353312 & 142596 & 1018409 & 761 & 4307 & 120 & 2938 \\
\hline MT & 0.725 & 0.732 & 0.635 & 1086843 & 269300 & 1898680 & 7882 & 11384 & 232 & 5533 \\
\hline MS & 0.729 & 0.740 & 0.629 & 1203191 & 135645 & 1286687 & 12371 & 21208 & 70 & 2578 \\
\hline$M G$ & 0.731 & 0.730 & 0.638 & 8825684 & 2217569 & 9787525 & 47955 & 21157 & 173 & 4558 \\
\hline GO & 0.735 & 0.742 & 0.646 & 2593851 & 518128 & 3470649 & 8589 & 39334 & 132 & 3790 \\
\hline RS & 0.746 & 0.769 & 0.642 & 9021918 & 626170 & 1553608 & 48850 & 14142 & 23 & 302 \\
\hline PR & 0.749 & 0.757 & 0.668 & 7613046 & 380200 & 3049544 & 15361 & 128361 & 73 & 1123 \\
\hline RJ & 0.761 & 0.782 & 0.675 & 7541131 & 2525723 & 6435387 & 28020 & 47488 & 39 & 1143 \\
\hline SC & 0.774 & 0.773 & 0.697 & 5830697 & 139727 & 845523 & 10750 & 12181 & 64 & 856 \\
\hline SP & 0.783 & 0.789 & 0.719 & 27399505 & 3122843 & 13329148 & 103058 & 540755 & 83 & 1529 \\
\hline $\mathrm{PI}$ & 0,646 & 0,635 & 0,547 & 692896 & 329844 & 2180547 & 3378 & - & 41 & 863 \\
\hline$A L$ & 0,631 & 0,641 & 0,52 & 901696 & 296366 & 2131168 & 9439 & 6292 & 8 & 799 \\
\hline
\end{tabular}

Source: Authors, elaborated using MTE (2016a) and PNUD/IPEA/FJP (2016).

Three questions emerge from the data presented. The first concerns the declaration of race and color in each state in relation to the number of workers rescued in the operations conducted by the MTE. Around $80 \%$ of the population in Pará do not declare themselves white, the state presenting the highest number of freed workers between 1999 and 2015 $(12,523)$. The majority of the population in the states of Mato Grosso, Minas Gerais, Goiás, Maranhão, Bahia, Tocantins and Mato Grosso do Sul also do not declare themselves white. The data thus indicate a relation between this variable and the practice of modern slavery.

Secondly, corroborating the data of Bales $(2004,2002)$, there seems to be an affinity between low indices of MHDI General, Income and Education (PNUD/IPEA/FJP, 2016) and the number of workers freed from 1999 to 2015 (MPT; OIT, 2017). This is 
deduced from the fact that the data show a coherent relation with the results of the number of workers freed. The states with a lower MDGI General, Income and Education - Maranhão, Pará, Bahia, Tocantins, Mato Grosso and Mato Grosso do Sul (PNUD/IPEA/FJP, 2016) - are those with a high number of rescues (MPT; OIT, 2017).

The third question concerns an opposite situation observed in the literature (Bales 2004) where the states of Minas Gerais, Goiás, Paraná, Rio de Janeiro and São Paulo present the highest levels of MHDI General and Income, but the number of workers freed by GEFM/MTE is also high. The high levels of MHDI, representing favorable socioeconomic conditions, should reduce the incidence of slave workers, yet this was not verified by the data. Only the MHDI Education of these states presents levels below the national average. Three possible explanations exist for this apparent contradiction: the first is the fact that the information on the number of rescued workers is incomplete, since the information system had yet to become fully effective. Hence fewer denunciations may exist in those states with a more precarious information system than the states of Minas Gerais, Goiás, Paraná, Rio de Janeiro and São Paulo. Another explanation is based on the difficulty of conducting inspections compared to the number of denunciations, which reflects the inconsistency in the figures obtained for slavery-like work in regions lacking adequate infrastructure, such as the Brazilian North and Northeast. A third possible explanation may be provided perhaps by the Gini index, which shows the conditions of inequality in these states and includes, in the analysis, the condition of vulnerability to which the lured workers are subjected. In sum, the assumption here is that the connection between the higher MDHI and modern slavery exists, but it should be remembered that this association is more complex than it seems and additional quantitative and qualitative studies are required for revealing further researches (DATTA; BALES, 2014; CRANE, 2013).

Figure 1 - Intensity of colors and measures showing location (municipality) of rescue, origin and residence of enslaved workers

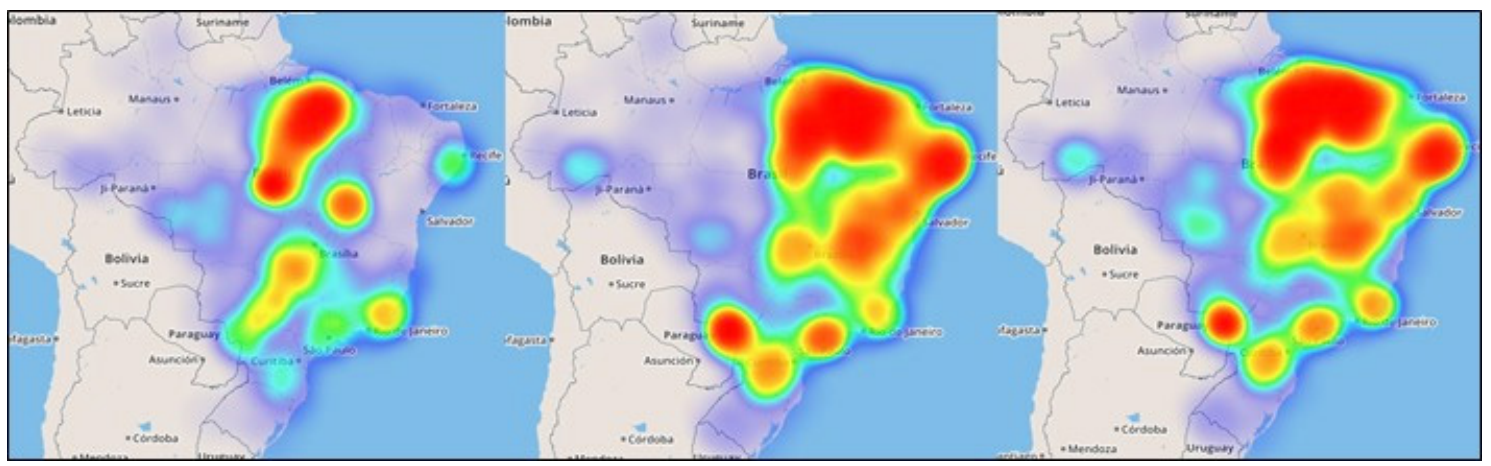

Source: Digital Observatory of Slave Labor in Brazil - Smartlab of Decent Work MPT (2017).

When data on the place of origin and residential status of the enslaved workers is observed, this configuration is confirmed. Figure 1 shows, from left to right, the municipalities where workers were rescued and their origin and residence.

The heat map in Figure 1 dynamically represents, in color, the levels of intensity of the occurrence of slavery-like work in Brazil (DIGITAL OBSERVATORY, 2017). The variation 
between cold and warm colors shows where there is a concentration of rescued workers their origin and their declared residence. From left to right, Figure 1 shows the highest concentration of rescued workers in the Northern region, followed by the Northeastern and Center Midwestern regions. A lower volume is evident in the South and Southeast compared to the North and Center West. In terms of origin, warm colors are more prevalent in many of the regions with lower intensity in the South, Southeast and Center West. As for residences declared by the workers rescued by GEFM/MTE, warm colors occur more in the Northern region, followed by the Northeast, Center West, Southeast and South. Since the activity with the highest incidence of slave labor is cattle farming and agriculture, it seems that the region on the fringe of Amazonia is a fertile area for luring workers into slave labor and for the re-occurrence of the practice. Vulnerability is characterized by the gap between the availability of material resources and the person's access to the structure of social opportunities (ABRAMOVAY, 2002; MOSER, 1998). This difference can result in disadvantages both for the worker's performance and for the risk of his or her social mobility ${ }^{6}$ (RODRÍGUEZ-VIGNOLI, 2001).

In the case of modern slavery, it can be observed that social (im)mobility is a direct result of the social conditions of vulnerability to which the potential victims are subjected and, consequently, could also be a predictor of re-occurrence in the dynamic of the game of slavery. The panorama of vulnerability is shown in Figure 2, based on three graphs produced from data taken from the Atlas of the Human Development (PNUD/IPEA/FJP, 2016). The first graph illustrates the MHDI General, the second shows the differences in life expectancy and the third indicates the Gini index for each state.

Figure 2 - Panorama of vulnerability in Brazil in the regions with the highest incidence of modern slavery
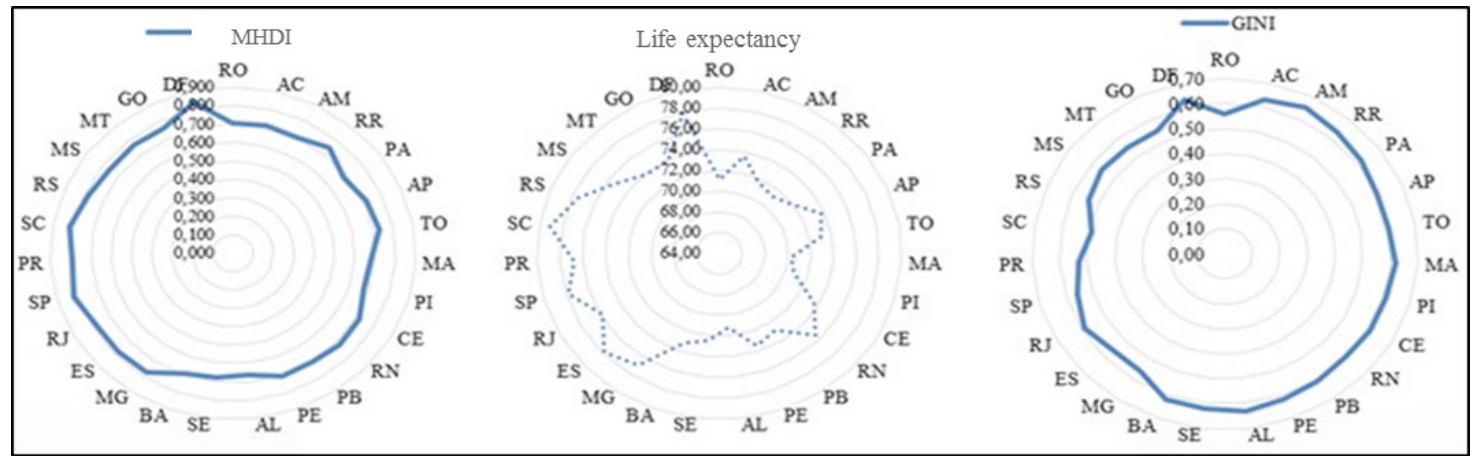

Source: Authors, adapted from the Atlas of Human Development (PNUD/IPEA/FJP, 2016).

The states with the highest indices of vulnerability are Maranhão, Alagoas, Piauí, Acre, Paraíba, Pará, Tocantins, Ceará, Bahia, Pernambuco and Rio Grande do Norte. These states are those with the worst conditions of health, access to education, child mortality and family structure (MHDI General), the lowest life expectancy at birth and the highest levels of social inequality (PNUD/IPEA/FJP, 2016). It is important to recall that the Gini coefficient

6. This relates to the capacity for socioeconomic change through access to resources associated with knowledge. 
registers the differences between social classes, with these states presenting almost the same value. The highest indices of vulnerability also coincide with the lowest municipal human development indices shown in Table 1.

Still in relation to the sociodemographic context, it is important to point out that vulnerability can also be characterized by indicators for race and color, gender and schooling. Based on cultural symbolic constructs (BOURDIEU, 1990), these characteristics may refer to and constitute a set of historically constructed beliefs that establish a consecrated status in relations of dependency and work. The data on freed workers between 2003 and 2017 was unavailable in the previous database which shows operations undertaken from 1999 to 2015 . The data also indicate that $48 \%$ of the individuals freed from slavery declared themselves mulato, caboclo, cafuzo, mameluco ${ }^{7}$ or mixed black with a parent of another color or race. $13.62 \%$ declared themselves black. Just 32\% declared themselves white (MPT; OIT, 2017). The demographic data from the latest IBGE Census (IBGE, 2016) show that $54.9 \%$ of Brazilians declared themselves black or brown $(46.7 \%$ as brown and $8.2 \%$ as black) and $44.2 \%$ declared themselves white. Therefore, compared to the last Census (2010), an increase was observable in the number of individuals declaring themselves black or brown. Hypothetically, this increase may be associated with a higher birth rate among the black and brown population, or greater individual self-recognition. Rescued white individuals comprise $32 \%$ of the total, while the data is worse for black workers, who comprise $14 \%$ of those rescued. Brown people account for $46.7 \%$ of the general population and $48 \%$ of those rescued, a higher equivalence than the case of black individuals who represent $8.2 \%$ of the population and $13.62 \%$ of those rescued.

However, the new database confirms that slave labor in Brazil has a definite race/ color identity, as can be seen in Figure 3.

In terms of the level of schooling of the freed workers, $40.29 \%$ are illiterate, $32.27 \%$ have not completed the fifth year of primary education. The data point to a strong indication of structural inertia reproducing individuals with very few years of study. The number of illiterate workers combined with those who completed up to five years of basic education totals $72.56 \%$, which represents 24,835 individuals freed from slave labor in Brazil between 2003 and 2017. In this case, Figure 3 measures the interaction between race, color, gender and schooling in relation to predictor variables of slave labor. In relation to gender, around $95 \%$ are men and 5\% women. Compiling and combining this data with the indices presented previously, it is possible to observe that slavery practice in Brazil shows a definitive identity based on these variables. It is important to note that men are associated with rural work and women are more associated with activities related to sexual purposes. Within this panorama, it should be emphasized that as a 'general rule,' enslaved workers present a profile of vulnerability associated with their socioeconomic condition and, because of a habitus consolidated by the different fields. This situation remains unchanged as long as there are no changes in this profile. In this sense, progress has been slow, despite all the efforts of actors in this field. The question of race/color does not appear in isolation since, historically speaking, in Brazil this variable has been connected to the person's sociocultural condition (MARTINS, 2008; FIGUEIRA, 2008). Bourdieu (1990, p. 136) argues that "the structure of the field is a state of the power relations among the agents or institutions

7. Brazilian terms for people of mixed ethnic origin (white, black and/or indigenous). 
engaged in the struggle". In the configuration assumed by modern slavery, this structure is also composed by this same profile, perpetuated in Brazilian society as one of the 'strategies' underlying the dynamic of the field of power. One example of this is perhaps the case of the maintenance of the state and the position of the actors: the consolidated position of the slave.

Figure 3 - Profile of workers rescued from slave labor between 2003 and 2017 by race/color, gender and level of schooling.
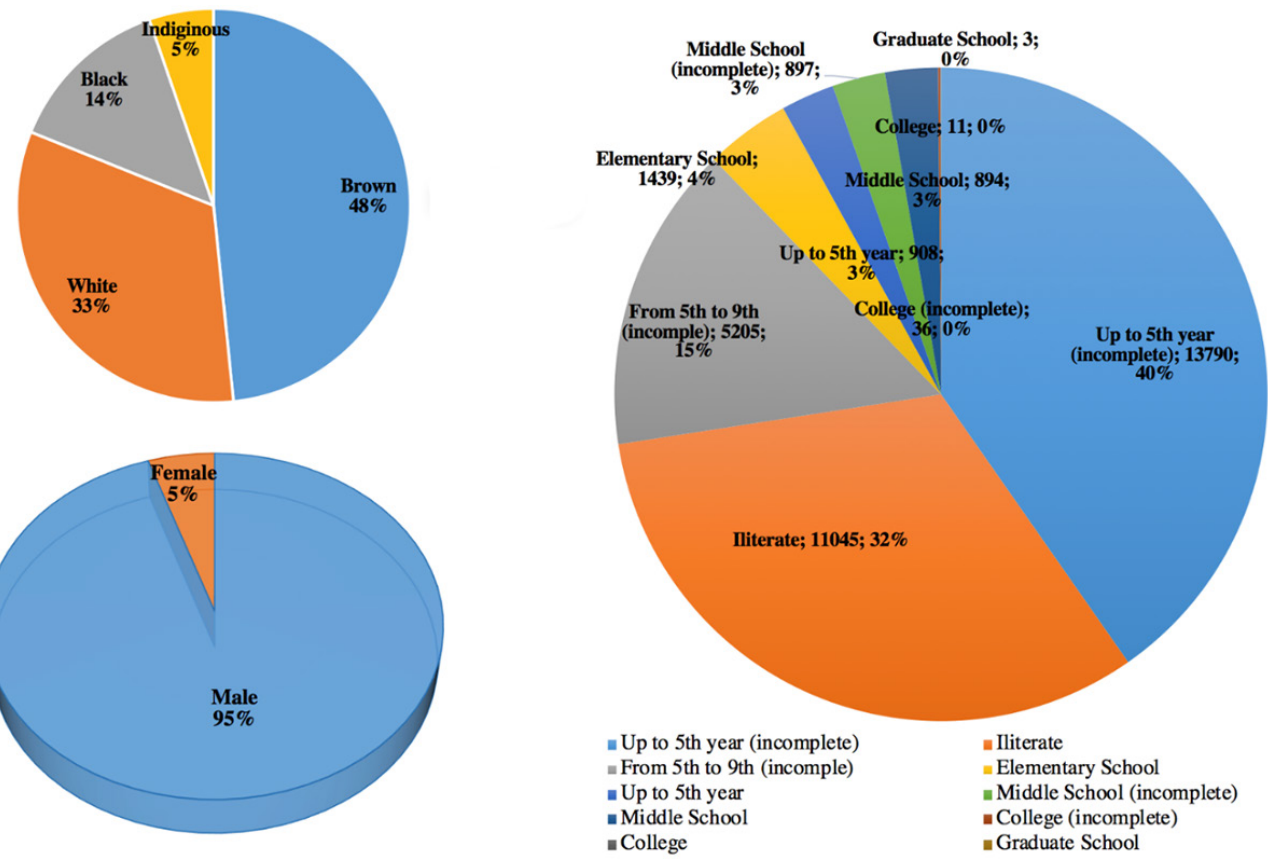

Source: Digital Observatory of Slave Labor in Brazil - Smartlab of Decent Work (2017).

In a survey conducted by ILO in 2011, in conjunction with GEFM/MTE, interviews made with 121 rescued workers were systemized. ${ }^{8}$ An underlying factor in the results was the question of social (im)mobility when the level of schooling of freed workers was compared to their parents'. Although $63 \%$ of rescued workers were illiterate or functionally illiterate, the percentage of parents who were in the same situation was higher. The data appears to show an improvement in access to formal education, indicated in the decline in the number of illiterate and functionally illiterate individuals to $18 \%$ and $45 \%$ respectively. However, even with an improvement in schooling, no social mobility occurred for these workers, demonstrating that this social structure may be sustaining contemporary slavery (FIGUEIRA, 2008). In summary, all the indications are that slave labor, in its modern form, presents a structure characterized by preferably luring black/brown individuals with low level of schooling, living in regions and states with low levels of development in health, education and income. The index of vulnerability can explain the higher probability of human

8. The ILO data was collected through interviews with workers freed in 2011 via the activities of the MTE's GEFM (Special Mobile Inspection Group). 
beings experiencing the eminence of becoming the targets of 'recruters' who lure them into degrading work that ends up enslaving them.

The ILO study (OIT, 2011) includes an important datum that has not been considered in the MTE's surveys, namely re-occurrence. The result shows that among the 121 interviewees, $59 \%$ had already been a victim of slavery in the past. This corroborates the reduced social mobility of individuals with low levels of education and income, principally for those declaring themselves black or brown.

On the other hand, the companies or organizations that promote the activities also constitute the field and reveal a "specific capital accumulated in past struggles", in the words of Bourdieu (1990, p. 136). Data from the MTE (2016a) and MPT (2017) ranked the economic activities that most reduce workers to a condition similar to modern slaves. The sectors showing the highest percentages in terms of the use of rural slave labor is beef cattle farming, rice cultivation, alcohol production, sugarcane cultivation, raw sugar production and logging in native forests. Combined, these activities correspond to $75 \%$ of the labor being exploited in conditions of analogous to modern slavery (DIGITAL OBSERVATORY, 2017). It is important to point out, however, that cattle farming and agriculture represent the economic activities with the highest number of inspections and rescues in the combatting of slave labor in Brazil and show the highest number of denunciations. Data also indicate that the municipalities with the highest number of inspections were São Feliz do Xingu-Pará, Açailândia-Maranhão, Marabá-Pará, Paracatu-Minas Gerais and Rondon do Pará-Pará. The municipalities with the highest number of rescues were Confresa-Mato Grosso, Ulianópolis-Pará, Brasilândia-Mato Grosso do Sul, Campos dos Goytacazes-Rio de Janeiro and São Desidério-Bahia. Data from the ILO (OIT, 2011) show that of ten farms inspected in the states of Pará, Mato Grosso, Bahia and Goiás, 44\% worked in activities linked to cattle farming, $17 \%$ coffee, cotton and soybean, $14 \%$ sugarcane, $19 \%$ tomato and $5 \%$ rice. The activities are diversified in regions like São Paulo and Rio de Janeiro where there are incidences of slavery-like labor in civil construction, the clothing industry and the manufacture of accessories. These municipalities are considered geographically isolated, conferring a degree of invisibility to the practice while at the same time hindering the access of the operations developed by the GEFM/MTE. The data on rescued workers likewise show evidence of human trafficking, especially when the origin of the enslaved workers is known to differ from the state where they were rescued.

Bribing, trading of influence to the benefit of third-parties and frauds may precede the slave labor practices themselves. In an interview, the auditor of GEFM/MTE (2011) ${ }^{9}$ from Campinas said: "[...] during the inspection of the lodgings it was observed that the workers had been lured in their town of origin, which is there [far away] in Piauí. They were transported in clandestine passenger vehicles, 220 reais for each one". The 'gato' ['cat'], the person who recruits and lures the workers, organizes and hires the clandestine transport, generally avoids federal highways and tries to 'buy' the inspectors to avoid the vehicle without a safety certificate from being impounded. In the case cited, the document required by the MTE for the transportation of workers, the worker transportation certificate, did not exist.

9. Verbal information provided during an interview with the Auditor of the Ministry of Labor and Employment (MTE), June $30^{\text {th }} 2011$. 
Data from the NGO Transparency International (2016) indicate that Brazil is perceived to suffer from high levels of corruption, occupying the $79^{\text {th }}$ place from 176 . From a range of 0 to 100 points, the country received just 40, showing a worsening trend from 2012 to 2015. According to the Coordinator of the NGO Repórter Brasil, attempts were made to corrupt the MTE-GEFM auditors at the Camargo Corrêa work site at the Jirau Hydroelectric Dam in Rondônia: "[...] even the fiscal auditor of Rondônia reports that a beam was about to fall on the head of five workers, but he was unable to suspend the work automatically. The auditor received a phone call from the manager of Camargo Corrêa: 'have you told your boss that you're going to stop the work here?'". ${ }^{10}$

Attempts are made to undermine the independence of GEFM/MTE's work by recourse to a hierarchical structure, linked to a political structure that has connections to companies such as Camargo Corrêa and Odebrecht. The attempt to impede the suspension of the work was justified by the delay in meeting the schedule. The cost of this interference is the risk of a serious accident, capable of taking a worker's life. Another situation was described as follows: "[...] we were going to call IBAMA to come here, but there's no way IBAMA can be called here, it's no good because news of the operation leaks, it leaks the day before". ${ }^{11}$ In this specific case, there was a structure linking IBAMA (Brazilian Institute of Environment and Renewable Natural Resources) to the company targeted by the MTE's inspections. The communication of this structure is established before the inspecting team arrives at the farm or the construction site. This structure may be the result of corruption and influence peddling.

Assuming the probable occurrence of modern slavery along with factors such as poverty, vulnerability, race/color and very low levels of education can form a starting point for deepening the discussion. Management systems work to promote a dynamic of modern slavery, with responsibility falling on the private sector, civil society and public authorities to elaborate public policies articulated with the institutional structure.

\section{DISCUSSION OF THE THEORETICAL PROPOSITIONS}

The qualitative results of the research, combined with the panorama presented and explored in more depth in the previous section, led us to construct five central propositions that are discussed here with the additional support of four real cases collected from the databases of the Ministry of Labor and Employment (MTE) in 2016. These propositions are founded on the theoretical categories (Table 4) proposed in the study and presented in summarized fashion in the table below.

10. Verbal information from the Coordinator of the NGO Repórter Brasil, on August $17^{\text {th }} 2014$ at the head office of the ILO in Brasilia.

11. Verbal information from the Coordinator of the NGO Repórter Brasil, on August $11^{\text {th }} 2014$ at the head office of the NGO Repórter Brasil. 
Table 4 - Theoretical categories of analysis

\begin{tabular}{|c|c|c|}
\hline $\begin{array}{c}\text { Categories of } \\
\text { analysis }\end{array}$ & Summary of the research & $\begin{array}{c}\text { Predictors of } \\
\text { modern slavery }\end{array}$ \\
\hline \multirow[t]{3}{*}{$\begin{array}{l}\text { Socio-econo- } \\
\text { mic context }\end{array}$} & $\begin{array}{l}\text { The global population has tripled over the last } 50 \text { years thanks to rural migra- } \\
\text { tion to the cities in Brazil and the rest of the world, intensifying the supply of } \\
\text { people seeking work and income, and lowering wages in rural areas and urban } \\
\text { centers. The urbanization rate in the } 1960 \text { s was } 57 \% \text { in the Southeast region, } \\
\text { reaching more than } 92 \% \text { in } 2010 \text {. The states of Maranhão, Piauí and Pará } \\
\text { present the lowest rates of urbanization in the country: } 59 \%, 67 \% \text { and } 70 \% \text {. } \\
\text { Production chains seek to lower production costs through the reduction of labor } \\
\text { costs, without investing in decent working conditions. } \\
\text { Formation and organization of cheap labor with mechanisms of substitution, } \\
\text { cheap production costs and cheap sales prices - formed an institutionalized } \\
\text { system combined simultaneously with low remuneration: outsourcing. Denun- } \\
\text { ciation to CADE for unfair pricing in the cattle farming chain. }\end{array}$ & $\begin{array}{l}\text { Population } \\
\text { density }\end{array}$ \\
\hline & $\begin{array}{l}\text { School attendance, lack of employment and income, as well as the lack of } \\
\text { resources for health are related to the incidence of slave labor in Brazil. Brazi- } \\
\text { lian slaves tend to originate from states with the country's lowest MHDI indices. }\end{array}$ & MHDI \\
\hline & $\begin{array}{c}\text { The state of poverty places individuals in direct line of fire with the luring } \\
\text { mechanisms used by 'gatos.' Begging, hunger, malnutrition, earthquakes and } \\
\text { migration can intensify the vulnerability of Brazilian and foreign workers. Certain } \\
\text { vulnerable regions ( } N \text { and NE) coincide with slave labor. }\end{array}$ & Vulnerability \\
\hline \multirow{2}{*}{$\begin{array}{l}\text { Geographic } \\
\text { context }\end{array}$} & $\begin{array}{l}\text { [...] "I'm a Northeasterner, I was born in a small town. There it is rare to find } \\
\text { good job opportunities. So it was normal to see family and friends leave for } \\
\text { other states in search of opportunities. In } 2011 \text { it was my turn to head south. } \\
\text { A man appeared in my town to recruit people, it was a project for a leading } \\
\text { construction firm, he said, good work, good wages, and travel costs, accommo- } \\
\text { dation and meals were covered. I needed [the work] and accepted it. After two } \\
\text { days in a coach, I arrived in São Paulo. And there the conversation changed. } \\
\text { [...] I thought about giving up and returning home, but I had no money for the } \\
\text { ticket and was obliged to stay" (MTE, 2016b). [...] "Pedro, } 13 \text { years old, lost } \\
\text { count of the number of times he felt cold, soaked by the Amazonian storms, } \\
\text { underneath the yellow tarpaulin tent that served as home during the week. } \\
\text { Before dawn he would gulp down black coffee thickened with manioc flour, grab } \\
\text { the } 14 \text { kilo chainsaw and begin work transforming the Amazonian forest around } \\
\text { him..." (OIT, 2007, p. 28) }\end{array}$ & $\begin{array}{l}\text { Geographic } \\
\text { isolation }\end{array}$ \\
\hline & $\begin{array}{l}\text { [...] "I didn't have an easy life. At } 14 \text { I ran away from home and my violent } \\
\text { stepfather. Since then I've worked hard, I always wanted to improve. That's why } \\
\text { I didn't think twice when a Brazilian appeared in La Paz. [...] I had two options, } \\
\text { pay the R } \$ 450 \text { for the trip or work for him for a year for no money. Without } \\
\text { any option, I submitted [to the latter]. I learnt to sew. I worked every day from } \\
7 \text { in the morning to } 11 \text { at night" (MTE, 2016c). CASE D [...] "immigration } \\
\text { is extremely high. We do not know how many Paraguayans, Bolivians and } \\
\text { Peruvians have already entered. Even Haitians, they caught } 200 \text { Haitians trying } \\
\text { to cross the border to work in the construction projects for the Olympics" (ILO } \\
\text { COORDINATOR, 2013, verbal information). [...] "we're about to host two major } \\
\text { events in Brazil, the World Cup and the Olympic Games, which are already } \\
\text { attracting [workers], including... coming from there in Mato Grosso, and there } \\
\text { are already reports of people arriving here in Brazil from outside the country, } \\
\text { and even migrating internally to work in these construction projects" (ILO } \\
\text { COORDINATOR, 2013). }\end{array}$ & $\begin{array}{l}\text { Human } \\
\text { trafficking }\end{array}$ \\
\hline
\end{tabular}




\begin{tabular}{c|c|c|c}
\hline Cultural \\
context & $\begin{array}{c}\text { [...] "there is a lot of resistance in the Brazilian congress, a lot of resistance } \\
\text { in various sectors of Brazilian society, to deepening affirmative action policies, } \\
\text { but clearly, a dividing line needs to be drawn between public policies and State } \\
\text { and civil society actions against slavery. It needs to be recognized that slaves in } \\
\text { Brazil are mostly black. Denying this fact is to fly in the face of reality" (Ministry } \\
\text { of Foreign Affairs 2011). Verbal information [... "look, we cannot accept that a } \\
\text { load of blacks and Africans board an overcrowded boat to try to reach Sicily and } \\
\text { there the boat sinks and they drown, so it's a human rights issue, what we have } \\
\text { to do to solve the problem is close the border" (COORDINATOR OF REPÓRTER } \\
\text { BRASIL, 2014). }\end{array}$ & Racer \\
\hline Regulatory & $\begin{array}{l}\text { [...] "in an operation in Goiás, GEFM released 128 workers in two farms. The } \\
\text { coordinator recounts that the inspection met with resistance despite the pre- } \\
\text { sence of the Federal Police. The farm managers did not reply to the questions, } \\
\text { ignored them and addressed them aggressively. They mocked the inspection. } \\
\text { Two civil police officers went to the location and even started interfering in the } \\
\text { inspection work until they were removed by the team from the Federal Police. } \\
\text { The mobile group confirms that the 'gato' has two brothers in the Civil Police } \\
\text { (COSTA, 2010, p.132). }\end{array}$ & $\begin{array}{c}\text { Corruption and } \\
\text { inspection }\end{array}$ \\
\hline
\end{tabular}

Source: Elaboration by the authors.

Proposition 1 - Socioeconomic context: contexts of high vulnerability such as unemployment, chronic poverty and low schooling stimulate the adoption of slave labor by some business ventures.

For Crane (2013), the hidden mechanism exploits vulnerable inert niches that become active due to the coordinated action of informal business ventures. The hidden mechanism refers to the operational logic of inert and vulnerable population niches that become active due to the coordinated action of informal ventures which use slave labor. These inert niches are characterized by the state of vulnerability and are associated with color/race in diverse regions of Brazil: in effect, they are black and brown. The hidden mechanisms are also associated with unsustainable management practices that the slavery-based network does not seem to deem necessary to explain or even defend when they reduce human beings to the condition of modern slaves.

The characteristics of slave labor are revealed in the degrading work conditions such as the lack of bathrooms, inadequate meals, exhausting working hours and unsafe work environments. Sugarcane harvesting is known to be arduous work that causes various health problems. Extreme physical and psychological violence and the phenomenon of poverty need to be understood in more depth. This is what Crane (2013) found in his study of the independent variables - poverty, vulnerability and education - since they need to undergo rigorous statistical testing in order for us to apprehend their correlation in any depth. The Municipal Human Development Index (MHDI) presents an average level in the states of Maranhão, Tocantins, Pará and Bahia, and a high level in the states of Mato Grosso and Mato Grosso do Sul. However, the data show that states like Minas Gerais, São Paulo, Rio de Janeiro, Santa Catarina and Paraná present a higher number of workers freed from 1995 to 2016 compared, for example, to the state of Piauí (PNUD/IPEA/FJP, 2016). Theoretically these states should present a lower number of enslaved workers due to their higher level of MHDI. Comparing, for example, the states of Piauí and Alagoas, both present a MHDI below these higher wealth-generating states, but also present a lower number of freed workers. The incidence of Piauí and Alagoas is higher in relation to workers born and rescued from slave labor in these states. Data show that the number of operations from 1995 to 2016 was 
higher in Pará, Mato Grosso and Minas Gerais. It seems that MHDI may be another condition for slave labor, but a double effect can be observed, which is similar to the one observed in relation to poverty (TONNEAU; AQUINO; TEIXEIRA, 2005). However, geographic data contained in the latter study show that where poverty exists, people are born in a state of vulnerability, later migrating to engage in work analogous to slavery (TONNEAU; AQUINO; TEIXEIRA, 2005).

Proposition 2 - Geographic context: The geographic isolation of the activity, combined with the psychological, political and physical isolation of the workers, stimulates the adoption of slave labor by some business ventures.

The incidence of freed workers and cities of birth of rescued workers is high in the states of Maranhão, Tocantins, Pará and Bahia, as well as Mato Grosso and Mato Grosso do Sul where the average percentage of the black population is $8.3 \%$ and the brown population 60.9\% (MTE, 2016; PNUD/IPEA/FJP, 2016). In relation to isolation, data from IBGE (2016) reveal that the states of Maranhão, Piauí and Pará present the country's lowest urbanization rates: $59 \%, 67 \%$ and $70 \%$, respectively, where the black and brown population show higher rates of migration in search of employment in large cities. Slave labor shifted from rural areas to the city due to the Brazilian population explosion and the mechanization of agriculture: [...] "the number of inspections of slave labor in urban operations has been growing in large-scale engineering projects and textile workshops" (COORDINATOR FROM THE NGO REPÓRTER BRASIL, 2014).

The Brazilian regions with the highest incidence of vulnerable workers are the frontier regions - the North and Northeast. Brazil takes in people coming from vulnerable situations in countries neighboring its northern region such as the French Guiana, Suriname, Guyana, Venezuela and Colombia, as well as Ecuador, Peru and Bolivia to the west, and Argentina and Uruguay to the south (ABRAMOVAY, 2002; MOSER, 1998; RODRÍGUEZ-VIGNOLI, 2001). Haiti has no border with Brazil, but the entry of Haitians into Brazil is explained by the 2010 earthquake, as well as the population's poverty and the friendly relation between the countries. The supply of vulnerable immigrants may form part of human trafficking, which lures people into economic or sexual exploitation. For example, Haitian workers were rescued from a construction site in Minas Gerais and another construction site for the Minha Casa Minha Vida housing program in Mato Grosso. The state of vulnerability also helps explain the problems some farmers face in obtaining agricultural loans (IBGE, 2016). It is extremely difficult for families living under the impacts of vulnerability to prove their income and capacity to pay as a requirement for obtaining these loans. The voluntary acceptance of a dangerous and undignified job appears in diverse testimonies from rescued workers and, it seems, may be associated with the vulnerable state of the individual concerned (LE BRETON, 2002; MTE, 2016).

Proposition 3 - Sociocultural and sociodemographic context: Inequality naturalizes coercive work relations, which stimulates the adoption of slave labor by some business ventures.

Data show that the Brazilian culture of acceptance is linked to the repertoire of coronelista traditions that implanted arduous and oppressive work routines over time (LE BRETON, 2002). The interaction of this repertoire with the spirit of honor of certain workers shows that modern slavery can be explained by the commitment of enslaved but honest wor- 
kers to pay unlawful debts: "[...] I'm a Northeasterner and I grew up listening to my father, who taught me to have the honor of paying for my debts and I'm going to pay for this debt no matter what". The habitus is consolidated through the permanent and continuous sociocultural and socioeconomic conditions that maintain contemporary slavery as an 'acceptable' practice in Brazilian society. These conditions are reproduced with the tacit agreement of all the actors who possess consolidated positions: companies, the local community, public authorities, institutions and the workers themselves. The oppressor culture shows a strong racial dimension insofar as it preferentially oppresses black and brown individuals, who, being more vulnerable, tend to assimilate oppressive labor practices as a natural fact of the workplace.

The social space is a product of the group's historical evolution and guides social practice. Sociocultural conditions cannot be seen merely as a static characteristic of a vulnerable social group of black and brown workers. They are the result of the permanent actions of a regulatory context that promotes public policies (which are still deficient) to reduce the conditions of vulnerability of this group. They are also articulated with the action of the companies and economic groups with their interests. Furthermore, they are similarly articulated with a set of beliefs, symbols and meanings that the local community shares. The fact that color/race and gender are associated with the profile of the enslaved worker is considered a correlated element, since the stereotypes are socially constructed, not biologically. In this sense, the habitus in the symbolic field of slavery in Brazil articulates the biological characteristic of black/brown with a social condition of vulnerability. And this consequently propels modern slavery.

Proposition 4 - Regulatory Context: The inefficiency of the regulatory context does not impose sanctions on the exploitation of labor in conditions analogous to slavery, which encourages the adoption of slave labor by some business ventures.

In prosecutions, the MTE, MPT and justice system argue that companies with more economic power, even when they establish a contract with their suppliers stipulating 'non-responsibility' for the workers under the latter's care, can be held jointly responsible if slave labor occurs. The TST (Superior Labor Court) of the state of São Paulo has sentenced companies for what it calls subsidiary responsibility. The prosecution argument shows that large retailers or stores introduce a fashion item designed by a professional stylist and at the end of the productive chain the outsourced and subcontracted workshops are obliged to produce the same model. This is what happened with the company Riachelo: "[...] the target, per hour, was to place elastic in 500 trousers or sew 300 pockets. [...] [workers] avoided drinking water to reduce the trips to the bathroom. Everything was controlled by the floor manager through the use of record cards. The former worker developed Carpal Tunnel Syndrome, which causes aches and swellings in the arms" (CAMPOS; ARANHA 2016, p. 2). The degrading conditions include the physical effort to sew without ever pausing to rest since the targets were inhumane, while meals had to be eaten at speed. Physical violence is characterized here through excessive work leading to Carpal Tunnel Syndrome. The time cards can be considered a hidden mechanism of degrading work that institutionalizes control and curbs the freedom of the workers who are required to meet inhumane targets. According to Campos and Aranha (2016), the legal action against Guararapes Confecções - a clothing factory from the Riachuelo Group - resulted in the requirement to pay a lifetime 
pension to the seamstress injured because of the work activities performed for the company. The company had decided to utilize a cost reduction strategy via outsourcing from 2013 and, because of the regulatory inefficiency of the public authorities in the inspection of subcontractors, the company failed to apply basic rules of the Consolidation of Labor Laws (Consolidação das Leis do Trabalho - CLT). According to Campos and Aranha (2016, p. 2), due to an agreement with 40 clauses that the company signed with the Ministry of Labor and Employment, the factory paid fines and had problems maintaining its competitiveness due to the reformulation of its costs.

\section{FINAL CONSIDERATIONS}

The aim of this article has been to identify the associations between the social conditions of vulnerability and the racial profile of contemporary slavery. Based on the results obtained in the research, the proposal of this study was to incorporate the race and color variable into the theoretical model conceptualized by Bales (2002; 2009), Crane (2013) and Datta and Bales $(2013 ; 2014)$ for its application in Brazil, proposing secondary data and primary sociodemographic and vulnerability indictors as predictors of modern slavery in the Brazilian context .

The sociodemographic data is redefined as sociocultural data when it becomes a component of social vulnerability. The declaration of race/color and gender are considered sociocultural elements of vulnerability due to their historical construction. In this sense, race/ color and gender may be strong conditions for the cyclical and permanent reproduction of modern slavery due to the social representation that they possess in the context. The explanatory model of contemporary slavery could be made more robust with the incorporation of these elements as components of sociocultural vulnerability.

According to the data presented, modern slavery in Brazil has a color. A clear relation exists between the black and brown population and slavery practices. Triangulation of the data from the 2010 IBGE Census with the data on enslaved workers released in Brazil by the MPT and MTE indicate an increase in black or brown individuals rescued in production chains in Brazil. Brown workers represent a higher percentage of people rescued from slave-like labor in comparison to black workers. Compared with the last Census in 2010, there was an increase in individuals declaring themselves black and brown. Hypothetically, this increase may be associated with higher birth rates among black and brown people, or greater individual self-recognition.

It seems that race/color can be a predictor variable for the probability of slavery occurring in Brazil, due to a historically constructed and socially reproduced context. The race/ color variable cannot be considered a determining factor for the existence of modern slavery, but without doubt it is a strong condition. The number of black and brown workers rescued in diverse regions of Brazil indicates a preponderance of the black population among those subjected to the condition of slaves. Despite presenting strong indications in this direction, future quantitative research and rigorous statistical tests are necessary for the race, poverty, $\mathrm{MHDI}$, vulnerability and education variables in order to better understand, for example, the moderating effect of these conditions and the persistence of slave labor. 
In terms of the empirical results, other implications and important findings were systemized. Firstly, it was possible to observe that contemporary slave labor coexists with the economically representative productive chains in Brazil and, indeed, with the signatory companies of InPACTO. The coexistence is consolidated in a relatively invisible organization run by 'gatos' or contractors who, in some cases, are themselves 'former slaves.' This difficult to perceive organization emerges in the rural environment of agribusiness and in the urban environment, particularly in civil construction and the textile industry (COSTA, 2010; MTE, 2012; 2016). These institutional arrangements are made possible by a context that in some form enables this articulation. For example, the research revealed that routines are developed and functions are delimited through actors and their interlinked structures, in which each actor occupies a consolidated position, combining interests, resources and strategies to maintain the structure (habitus) and the game. Besides the direct actors ('gato,' farm owner, cook, hotel owner, workers), the indirect actors also sustain this dynamic. The relation of dependency between workers and slave organizations completes the picture, given that it is strongly influenced by hidden mechanisms related to extreme violence and murders involving bosses, 'gatos,' workers and other suppliers, taking advantage of the sociocultural and economic-political conditions of structural inertia (CRANE, 2013, DATTA; BALES, 2014).

From the survey, it can also be observed that a significant lacuna exists in the Brazilian legal framework, derived from a definition of the concept that does not expressly recognize forced or compulsory labor as modern slave labor. The existence of this lacuna in an environment with a high possibility of corruption sets the terrain for the development of an ambiguous political struggle in which some institutions can use the very legal and regulatory frameworks to promote the practice of slavery. This can be observed in the definition of the crime and in the existing institutional arrangements. In turn, this configuration points to one of the implications of the study, namely its exposure of the maneuvers adopted by certain companies or farmers in response to the GEFM inspections through lawyers aware of the impact of the 'dirty list' and, very often, ready with an appeal to submit to the courts. A defense mechanism has developed to avoid punishment involving restrictions on loans intended for agribusiness.

In the Brazilian context, the slave practices in chains of cattle farming, agriculture, civil construction and the textile industry persist concomitantly with the 'responses' to the institutional regulatory pressures, monitored by InPACTO or the 'dirty list,' and to the prices of a competitive market. This response demands that some links in the chain adapt to meet the market and the regulatory environment. Another implication of the study showed that the actors participating in the production chain do not communicate with all the links of the chain, and do not detect or correct the potential slavery practices (GOLD; TRAUTRIMS; TRODD, 2015). There is a need for companies to assume the role of managing the entire production chain, for example, by implementing technology and management of people in a participatory manner, not only by means of audits or certifications. This participatory activity can be developed with the cooperation of interested NGOs and institutions, such as InPACTO, principally in the first links of the chain, in order to promote the eradication of contemporary slave labor.

The study's limitations are associated with the scant attention paid by some companies to the issue of slave labor in production chains. Along these lines, over the course 
of the study a strong sense of distrust and self-protective responses were perceived, which limited the number of interviews that could be conducted, especially with companies. However, participation in seminars and presentations held by InPACTO in São Paulo and Brasilia, along with a visit to the ILO head office in Brasilia, was used as a strategy to collect primary data and triangulate this material with the secondary data.

The path for future research involves a better understanding of 'whether' and 'how' institutional deformity can hinder the instruments used to combat slave labor in Brazil. Consequently, a research agenda is proposed that emphasizes the unsustainability of aspects of the globalization of production and consumption. A research agenda is also proposed, that prioritizes modern slave labor as a central rather than peripheral problem, investigating the role of the MTE, the MPT and the Federal Attorney General (AGU), alongside NGOs and ILO. It is necessary to rigorously investigate the independent variables such as race/color, poverty and vulnerability associated with the incidence of slave labor in certain regions. In addition, an opportunity is created to better comprehend how the creation of institutions can contribute to the discussion of alternatives and the proposal of solutions to problems.

The results point to the need to examine, in more depth, how economically representative supply-chain companies can implement the audits and routines of international certification practices so as to reach the invisible organizations formed and maintained by 'gatos' or contractors. Another opportunity for future research resides in understanding how organizational capacities are developed to meet institutional demands and, along the same lines, which of these demands are related to the promotion of racial integration in the management of diversity. The study also opened up a range of opportunities to the activities of NGOs, companies and the public authorities in the formulation of public policies to combat slave labor - its articulations, interests, hidden mechanisms and interferences. Such approaches need to problematize the racial dimension of slave labor in the country's sociodemographic and economic composition, reflecting its historically constructed trajectory. By recognizing that the Brazilian population has a historical legacy, still present in the forms of treating the racial profile in organizations and in information on slave labor, such an initiative would help make public and private actions more effective. Ignoring this perspective, on the contrary, means perpetuating certain conditions of vulnerability and colluding with the persistence of an inhumane organizational practice.

\section{REFERENCES}

ABRAMOVAY, M. Juventude, violência e vulnerabilidade social na América Latina: desafios para políticas públicas. UNESCO, BID: Brasília, p. 1-192. 2002.

AGUINIS, H.; GLAVAS, A. What we know and don't know about corporate social responsibility. Journal of Management, Cambridge, MA, v. 38, n. 4, p. 932-968, 2012.

BALES, K. International labor standards: quality of information and measures of progress in combating forced labor. Scientific American., v. 24, n. 2, p. 321-364, 2002.

Disposal People: new slavery in global economy. Califórnia: Califórnia Press, 2004. Trabalho Escravo. In: SEMINÁRIO DO PACTO NACIONAL PARA ERRADICAÇÃO DO TRABALHO ESCRAVO, 4., 2011, Brasília. Anais... Brasília: OIT, 2011. 
BALES, K.; ROBBINS, T. No One Shall Be Held in Slavery or Servitude: A Critical Analysis of International Slavery Agreements and Concepts of Slavery. Human Rights Review., v. 2, n. 2, p. 18-45, 2001.

BALES, K.; SOODALTER, R. The Slave Next Door. Human Trafficking and Slavery in America Today. University of California., 2009.

BALES, K.; TRODD, Z.; WILLIAMSON, A. K. Modern Slavery: The Secret World of 27 Million People. London: Oneworld Oxford, v. 1, 2009. 224 p.

BALLOU, R. H. The evolution and future of logistics and supply chain management. European Business Review, v. 19, n. 4, p. 332-348, July 2007.

BARDIN, L. Análise de conteúdo. Lisboa: Edições 70, 1977.

BECKER, G. S. Crime and punishment: An economic approach. Journal of Political Economy, v. 76, n. 4, p. $169-217,1968$.

BOURDIEU, P. 0 poder simbólico. Lisboa, PT: Memória e Sociedade, 1989.

. El campo científico. In: . Los usos sociales de la ciencia. Buenos Aires: Nueva Visión, 1990, p. 9-57.

BRASIL. Presidência da República. Lei 10.803, de 11 de dezembro de 2003. Altera o art. 149 do decreto-lei n. 2.848, de 7 de dezembro de 1940 - Código Penal para estabelecer penas ao crime nele tipificado e indicar as hipóteses em que se configura condição análoga à de escravo. Diário Oficial [da] República Federativa do Brasil, 12 de dezembro de 2003, p.1. Available on: <http://www.planalto.gov.br/ccivil_03/Leis/2003/L10.803.htm>. Acessed on 11 mar. 2017.

CNJ. Conselho Nacional de Justiça. "OSCAR" Judiciário: CNJ premia juízes e desembargadores por decisões pró-direitos humanos. Revista Consultor Jurídico, 14 de fevereiro de 2017. Available on: <http://www.conjur.com.br/2017-fev-14/cnj-premia-juizes-decisoes-favor-mulheres-idosos-indios > . Acessed on 25 ago. 2017.

CAMPOS, A.; ARANHA, C. Condenação do grupo Riachuelo revela o adoecimento das trabalhadoras da moda. ONG Repórter Brasil, 2016. Available on: <http://reporterbrasil. org.br/2016/01/condenacao-do-grupo-riachuelo-revela-o-adoecimento-das-trabalhadoras-da-moda/>. Acessed on 11 mai 2016.

CAZETTA, U. A escravidão ainda resiste. In: ENCONTRO DOS AGENTES PÚBLICOS RESPONSÁVEIS PELO COMBATE AO TRABALHO ESCRAVO, 1., Brasília, 2007. Anais... MPT. Ministério Público do Trabalho. Brasília, p. 105-136. 2007.

COOKE, B. The Denial of Slavery in Management Studies. Journal of Management Studies, v. 40, n. $8,2003$.

COSTA, P. T. M. Combatendo o trabalho escravo contemporâneo no Brasil: o exemplo do Brasil. Organização Internacional do Trabalho: Brasília, 194p. 2010.

CRANE, A. Modern slavery as a management practice: exploring the conditions and capabilities for human exploitation. Academy of Management Review, York, v. 38, n. 1, p. 53, 14 Feb 2013. 
DATTA, M. N.; BALES, K. Slavery in Europe: Part 1, Estimating the Dark Figure. Human Rights Quarterly, v. 35, p. 817-829, 2013.

. Slavery in Europe: Part 2, Testing a Predictive Model. Human Rights Quarterly, v. 36, p. 277-296, 2014.

DICK, A. R. When does organized crime pay? A transaction cost analysis. International Review of Law and Economics, v. 15, p. 25-45, 1995.

DIMAGGIO, P. J.; POWELL, W. W. The iron cage revisited: Institutional isomorphism and collective rationality in organizational fields. American Sociological Review, v. 48, n. 2, p. 147-160, 1983.

FIGUEIRA, R. R. Pisando fora da própria sompra. In: CERQUEIRA, G. C. de et al. (Org.). Trabalho escravo contemporâneo no Brasil: contribuições críticas para sua análise e denúncia. Rio de Janeiro: UFRJ, 2008. v. 1, p. 87-110.

GOLD, S.; TRAUTRIMS, A.; TRODD, Z. Modern slavery challenges to supply chain management. Supply Chain Management: An International Journal, v. 20, n. 5, p. 485-494, 2015.

HOWE, K.; EISENHART, M. Standards for Qualitative (and Quantitative) Research: A Prolegomenon. Educational Researcher, v. 19, n. 4, p. 2-9, 1990.

IBGE. Instituto Brasileiro de Geografia e Estatística. População - Projeções e Estimativas da População. 2016. Available on: <http://www.ibge.gov.br/apps/populacao/projecao/>. Acessed on 11 mai 2016.

INPACTO. Instituto Pacto Nacional pela Erradicação do Trabalho Escravo. Histórico. 2015. Available on: <http://www.inpacto.org.br/inpacto-2/historia/> . Acessed on 16 Abril 2015.

LE BRETON, B. Vidas roubadas. A escravidão moderna na Amazônia brasileira. São Paulo: Loyola, v. 2, 2002. 278p.

LINDSAY, D. M. Organizational liminality and interstitial creativity: the fellowship of power. Social Forces, v. 89, n. 1, 2010. p. 163-184.

LINSTEAD, S.; MARÉCHAL, G.; GRIFFIN, R. W. Theorizing and Researching the Dark Side of Organization. Organization Studies, v. 35, n. 2, p. 165-188, 2014.

LUXEMBURGO, R. A acumulação do capital: contribuição ao estudo econômico do Imperialismo. São Paulo: Abril Cultural, v. 1 e 2, 1984.

MPT. Ministério Público do Trabalho. OIT. Organização Internacional do Trabalho. Observatório digital do trabalho escravo no Brasil. 2017. Available on: <https://observatorioescravo. mpt.mp.br/>. Acessed on 01 mar. 2018.

MTE. Ministério do Trabalho e Emprego. Perguntas e Respostas sobre Trabalho Análogo ao de Escravo no Brasil. Já fizemos muito e estamos trabalhando por mais. MTE: Brasília, p. 1-15. 2009.

. Manual de Combate ao Trabalho em Condições análogas às de escravo. MTE: Brasília, p. 1-97. 2011.

. Trabalho Escravo no Brasil em Retrospectiva: Referências para estudos e pesquisas. MTE: Brasília, p. 1-33. 2012. 
MTE. Ministério do Trabalho e Emprego. Governo atualiza regras para inclusão de empresas na lista suja do trabalho escravo. 2016. Available on: <http://trabalho.gov.br/ noticias/3392-governo-atualiza-regras-para-inclusao-de-empresas-na-lista-suja-do-trabaIho-escravo >. Acessed on 19 mai 2016.

. Trabalho em situação análoga à escravidão. Depoimento 1. 2016a. Available on: <http://trabalho.gov.br/trabalhoescravonao/> . Acessed on 20 mai 2016.

. Trabalho em situação análoga à escravidão. Depoimento 2. 2016b. Available on: <http://trabalho.gov.br/trabalhoescravonao/>. Acessed on 20 mai 2016.

. Trabalho em situação análoga à escravidão. Depoimento 3. 2016c. Available on: <http://trabalho.gov.br/trabalhoescravonao/>. Acessed on 20 mai 2016.

. Trabalho em situação análoga à escravidão. Depoimento 4. 2016d. Available on: <http://trabalho.gov.br/trabalhoescravonao/>. Acessed on 20 mai 2016.

MARTINS, J. S. D. A sociedade vista do abismo. Novos estudos sobre exclusão, pobreza e classes sociais. 3 ed. Petrópolis, RJ: Vozes, 2008.

MELO, L. C. A. Atuação do Ministério Público do Trabalho no Combate ao trabalho Escravo - crimes contra a organização do trabalho e demais crimes conexos. Organizaçao Internacional do Trabalho: Brasília, DF., p. 64-103. 2007.

MOSER, C. O. N. The asset vulnerability framework: Reassessing urban poverty reduction strategies. World Development, v. 26, n. 1, p. 1-19, 1998.

OIT. Organização Internacional do Trabalho. Uma Aliança Global Contra o Trabalho Escravo. Relatório Global do Seguimento da Declaração da OIT sobre os Princípios e Direitos Fundamentais no Trabalho. Organização Internacional do Trabalho, Secretaria Internacional do Trabalho: Genebra, 2005. Available on: <https://reporterbrasil.org.br/documentos/relatorio_global2005.pdf>.

O custo da coerção. Relatório Global do Seguimento da Declaração da OIT sobre os Princípios e Direitos Fundamentais no Trabalho. Bureau Internacional do Trabalho: Genebra, 2009. Available on: <https://reporterbrasil.org.br/documentos/relatorio_oit_2009. pdf $>$.

. Combate ao trabalho forçado: manual para empregadores e empresas. Organização Internacional do Trabalho: Brasília, 176p. 2011.

Profit and Poverty. The economics of forced labour. International Labor Organization: Genebra, 66p. 2014.

PENNINGTON, J. R. et al. The Cross-National Market in Human Beings. Journal of Macromarketing, v. 29, n. 2, p. 119-134, 2009.

PROGRAMA DAS NAÇÕES UNIDAS PARA O DESENVOLVIMENTO. INSTITUTO DE PESQUISA ECONÔMICA APLICADA. FUNDAÇÃO JOÃO PINHEIRO (PNUD/IPEA/FJP). Atlas do Desenvolvimento Humano. Dados do índice de desenvolvimento humano - IDHM e IDH. Atlasbrasil.org.br, São Paulo, p. 1-2, 2016. Available on: <http://www.atlasbrasil.org. br/2013/pt/ranking > . Acessed on 19 marc 2016. 
REPÓRTER BRASIL. Home. Available on: <http://reporterbrasil.org.br/>. Acessed on 10 Agosto 2011.

RODRÍGUEZ-VIGNOLI, J. Vulnerabilidad y grupos vulnerables: un marco de referencia conceptual mirando a los jóvenes. Santiago de Chile: NU/Cepal/Eclac, 62p. 2001. Available on: $\quad<$ https://www.cepal.org/es/publicaciones/7150-vulnerabilidad-grupos-vulnerables-un-marco-referencia-conceptual-mirando-jovenes $>$.

SAKAMOTO, L. A economia do trabalho escravo no Brasil contemporâneo. In: CERQUEIRA, G. C. et al. Trabalho Escravo Contemporâneo no Brasil: Contribuições críticas para sua análise e denúncia. Rio de Janeiro: Editora UFRJ, v. 1, 2008. p. 61-71.

SALT, J.; STEIN, J. Migration as a business: the case of trafficking. International Migration, v. 35, n. 4, p. 467-494, 2002. doi: 10.1111/1468-2435.00023.

SÃO PAULO. Governo do Estado. Secretaria da Justiça e da Defesa da Cidadania. Secretaria de Gestão Pública. Tráfico de Pessoas e Trabalho Escravo no Estado de São Paulo. Análise dos procedimentos judiciais e extrajudiciais do Ministério Público do Trabalho e Ministério Público Federal. São Paulo: SJDC/SGP, 96p. 2015.

SECCHI, L. Políticas Públicas: conceitos, esquemas de análise, casos práticos. São Paulo: Cengage Learning, 2010.

SCOTT, R. W. Institutions and organizations. Thousand Oaks, CA: Sage, 1995.

TONNEAU, J.-P.; AQUINO, J. R. D.; TEIXEIRA, O. Modernização da agricultura familiar e exclusão social: o dilema das políticas agrícolas. Cadernos de Ciência \& Tecnologia, Brasília, v. 22, n. 1, p. 67-82, 2005.

TRANSPARENCY INTERNACIONAL. Corruption perceptions index 2016. 2016. Available on: <https://goo.gl/wKga9k>. Acessed on 11 fev. 2018.

UNITED NATIONS. Human trafficking fastest growing form of organized crime: UN anti-crime chief. United Nations News, 01/11/2001, Available on: <http://www.un.org/apps/ news/story.asp?NewsID=2007\&Cr=\&Cr1 =\#.UFEljbJISq9>. Acessed on 09 Julho 2017.

WALK FREE FOUNDATION. The Global Slavery Index. Slavery Alert: Consumer Poll, Brazil. Walk Free Foundation: New York, USA, 9p. 2014. Available on: <https://www. walkfreefoundation.org/news/resource/slavery-alert-consumer-poll-brazil/>

WEBB, J. W. et al. You say illegal, I say legitimate: entrepreneurship in the informal economy. Academy of Management Review, v. 34, p. 492-510, 2009.

Data de submissão: 30/09/2017.

Data de aprovação: 24/07/2018.

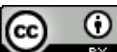

Creative Commons Atribuição 4.0 Internacional

Note: you can find this paper in Portuguese at http://www.revistaoes.ufba.br. 